April 2012

\title{
Against the Grain: Critical Reflections on the State and Future of Genocide Scholarship
}

Henry C. Theriault

Follow this and additional works at: https://digitalcommons.usf.edu/gsp

\section{Recommended Citation}

Theriault, Henry C. (2012) "Against the Grain: Critical Reflections on the State and Future of Genocide Scholarship," Genocide Studies and Prevention: An International Journal: Vol. 7: Iss. 1: Article 12.

Available at: https://digitalcommons.usf.edu/gsp/vol7/iss1/12

This Articles is brought to you for free and open access by the Open Access Journals at Digital Commons @ University of South Florida. It has been accepted for inclusion in Genocide Studies and Prevention: An International Journal by an authorized editor of Digital Commons @ University of South Florida. For more information, please contact digitalcommons@usf.edu. 


\title{
Against the Grain: Critical Reflections on the State and Future of Genocide Scholarship ${ }^{1}$
}

\author{
Henry C. Theriault \\ Worcester State University
}

\begin{abstract}
This article critiques certain trends in genocide studies, including scholarly misuse of Lemkin's status and work, retreat from academic activism against genocide, dismissive approaches to victim groups' political agency, relativist tendencies of the "memory politics" concept and its application, growing institutionalization of the field, the obscuring of genocidal violence against women and girls through the concept of "gendercide," the focus on dehumanization as a condition of genocide, and the emphasis on early warning. The article also discusses a new genocide denial strategy. In light of this, genocide early warning is largely irrelevant and, far beyond political indifference accounting for the continued prevalence of genocide, the prevalence results because the current global order and many individual societies have been largely formed through genocide and related mass violence and oppression. The article contends that a global reparation process could help rework the current world away from its genocidal foundations and tendencies.
\end{abstract}

Key words: Lemkin, memory politics, gendercide, dehumanization, genocide prevention, reparations

This article examines certain current issues and trends in genocide studies. Some are topics that have garnered sustained attention in recent years, while others are issues that are not well-studied but that I consider important for the future of the discipline. While this article recognizes important strides represented by various recent activities in the field as well as the typically well-considered overarching emphases of the field, the received topics are engaged critically in an effort to expose problematic assumptions, gaps, and other points for analysis and open them to new insights and directions. Through an identification of under-discussed issues, this article subjects the field as a whole to similar critique to open new avenues of inquiry or effort.

While the article aims at the specific rather than the abstract, the goal is not a sequence of direct evaluative engagements with particular scholars and works. There are two main reasons for this. First, the purpose of the article is to look at the overall features of the field as well as where it is and where it should go in the near future. However productive commentaries on particular scholars might be as part of that process, too specific a focus will mean, in a short work, losing sight of the general issues at stake. Second, while scholarly history is one of the last places where the obsolete "great man" of history model is still used (note the concept of "pioneers of genocide studies," for example), the evolution of a field of study is driven by a complex of global and particular forces and situational factors that include individual desires and acts but are not exhausted by them. Individual work is a function of these trends as much as or more than it is some kind of core, independent, individual intellectual activity. This is not to say that work in genocide studies is derivative, though it is the case that many recent trends- "gendercide," colonialism and genocide, and so forth-are in essence the result 
of (rather belated) applications of long-standing, even institutionalized, scholarly and intellectual movements-gender studies, postcolonial and subaltern studies, and so forth-to the particular subject of genocide. Indeed, while certain individuals might have attached themselves or been attached to particular trends in the field, the reality more typically is that multiple independently working scholars were moving toward similar ideas.

The applications of external theoretical frameworks is not a bad trend at all. Quite the contrary, the incorporation of postcolonial theory, for instance, is quite welcome and has advanced the field. What is more, the interaction between such an approach and the study of genocide is clearly advancing postcolonial theory as well, just as the application of Holocaust studies approaches to other genocides actually reflected back into the former in productive ways-for instance, in the treatment of denial. But a focus on scholars in the field misses the long intellectual traditions outside it that are the foundation of this kind of work in genocide studies.

The topic of the field itself is an interesting issue. A decade ago, scholars referred to the field as "comparative genocide studies" and emphasized the notion that the range of cases of genocide, including the Holocaust, should be understood as part of a broad phenomenon through analysis of the similarities (and differences) among various cases. This might be seen as a response to the now undiscussed but once hotly debated issues of the comparability of the Holocaust and of Holocaust studies versus Holocaust and genocide studies versus genocide studies. In any event, the "comparative" modifier has in recent years been dropped, perhaps in recognition of the broadness of the field, which in one sense subsumes, in addition to comparative analysis, all discrete studies of particular cases of genocide as well as abstract theoretical discussions that do not focus on specific cases.

The mention of the "great man" theory of history suggests a first point of analysis. This is the recent increase in attention to Raphael Lemkin. While a re-examination of his work as the source of multiple interesting ideas that have not been tapped and have even been set aside is useful for the field, as is the publication of writings that have been heretofore the province of a very select set of scholars, the culture that is growing around Lemkin has led to what might be called a "Lemkin fundamentalism," according to which present moves in scholarship are justified by appeal to Lemkin's authority (this or that is what he really meant by the concept of genocide) rather than by the merits of the positions themselves. While a respectful recognition that what appear to be new ideas were anticipated by Lemkin is certainly a mark of humility and to be lauded-indeed, in particularly gifted scholars' hands, it marks an attempt to go back in the history of genocide studies to reactivate strands of thought that were truncated in favor of the particular path that has evolved (for instance, the legalistic approach to genocide, the discounting of structural processes, ${ }^{2}$ and the nearly exclusive emphasis on killing $^{3}$ ) - an overemphasis on Lemkin runs the risk of stifling new possibilities that he did not anticipate. This is typically not noticed adequately because the very notion of genocide is viewed as a static universal, fixed across place and for all time, in the manner in which Plato conceived "Virtue," "Justice," and the like. Genocide, however, is not a natural object; it is a set of historical events or processes that have been grouped together by a common term, typically based on a set of shared characteristics that have been deemed, relative to the prevailing ethical views of a time and place, of special importance, but sometimes also or instead based on a historical lineage or some other 
factor serving to unify particular cases. Lemkin had as his reference data only acts prior to 1944, when he announced coining the term. While he is to be lauded for having deep insights into the nature of the genocidal processes, his insights are limited by his location at a particular point in history. Just as a theorist of the ancient world would have had a different concept of genocide-we cannot say more limited because it could have involved nuances and insights that would not have been available later-from Lemkin, so would Lemkin writing today have a different concept and definition from the one that he developed seven decades ago. Indeed, in direct proportion to the gains in global political, legal, media, and public attention, the concept and practices of genocide have evolved in ways that show perpetrators' awareness of the most likely bases of intervention and prosecution. Some approaches to genocide appear in fact modified to avoid generating the most obvious evidence of genocide. For instance, the extensive use of systematic sexual violence as a tool of ethnic depopulation/ repopulation, community destruction, and genocidal dispersion by Serbian forces in Bosnia-Herzegovina, coupled with a lower incidence of direct killing than in similar cases, suggests a witting or unconscious modification of typical approaches to genocide to decrease the likelihood of international intervention. The modification was quite successful, for despite evidence of tens of thousands of rape victims (each often raped dozens if not hundreds of times) over multiple years, it was only after the direct killing of thousands of men and boys in Srebrenica that the international community took decisive action. ${ }^{4}$

If we switch focus from the limitation of theorizing genocide based on Lemkin's approach to exclusive focus on Lemkin historically, we might recognize a related "Lemkin fetishism." A key example is Samantha Power's journalistic use of Lemkin as a hook-that is, a rhetorical, even propagandistic, device-to entice, even manipulate, readers into a particular kind of engagement with her subject matter. ${ }^{5}$ While Lemkin certainly deserves credit for coining the term "genocide" and being the founding scholar of genocide studies, exclusive focus on him as the major historical figure in the long process of development of the concept of genocide within the broader notion of human rights authorizes a fetishism of Lemkin that ignores a much fuller history which includes such things as Morgenthau's use of the term "race extermination,"6 Rousseau's ethical argument against genocide, and even Thucydides's work on the Melos Genocide. ${ }^{7}$

A second issue is the "theory-practice" distinction. While clearly it is possible to engage in theoretical work-such as defining genocide-without regard to its practical implications and just as possible to do concrete work-for instance, in a camp of refugees from a genocide-without attempting to theorize the forces producing the context in which the concrete work is being done, practical implications are implicit in theoretical work and concrete work demands theorization. Thus, the all-too-frequent dismissal of academics by public policy makers, non-governmental organization (NGO) workers, and others ignores the fact that such people are always already operating within theoretical frameworks to which they are typically blind. The choice of how to approach refugee work is often terribly ideologically loaded, while policy practitioners focused exclusively on "political realities" and rejecting any kind of ethical concerns are actually committed to a specific ethical theory themselves-that of privileging practical interests over other considerations. A person's “on the ground" activities are mediated through ideological structures embedded in his or her mind, institutional practices, and structures; geopolitical forces and trends supporting these institutions and the individuals 
operating within them; occupational and organizational attitudes, language games, boundaries, blind spots, and so on-that is, mediated through mental structures infinitely distant from "the ground" precisely because they prevent direct interaction with what is happening on the ground on its own terms.

Recent condemnations of activist scholars are at once appropriate and incorrect. It is appropriate to call attention to the politicized nature of genocide scholarship, but it is incorrect to pose a depoliticized, "objective" alternative of pure scholarship. Regarding the first point, there is clearly the potential to tap, exploit, or taint scholarship on genocide for or with particular political agendas. For instance, those pushing for an increase in military spending by the United States might cite the Responsibility to Protect as a moral imperative that requires the expansion of the capacity of the US military for civilian protection operations. What is more, powerful interests are always already fully present in universities and NGOs. In the US, Department of Defense funding for all sorts of programs is rampant, for instance, while the apparent exculpatory influence of powerful US political elites on the representations of the Rwandan and Armenian Genocides in the Albright-Cohen report suggest deep problems with the US Institute of Peace. ${ }^{8}$ Perhaps the most significant danger today is the growing militarization of genocide studies. Through such mechanisms as Mass Atrocity Response Operations: A Military Planning Handbook, ${ }^{9}$ scholars researching mass violence are being pulled into the orbit of the US military. The lessons of the US invasion of Iraq that has been (partially) justified on humanitarian grounds-as has the invasion of Afghanistan, for instance, with the aim to free women and girls from the oppressive yoke of the Taliban-are clear: as human rights and anti-genocide discourse has gained greater and greater public presence and moral legitimacy, it is more and more appropriated as a rhetorical cover for the pursuit of other, less laudable, agendas. Just as with Lemkin, Samantha Power's work in this regard has been as problematic as it has been effective. Her "A Problem from Hell" is, in fact, an extended polemic designed to convince members of the US public that military violence is the one and only correct and effective response to the problem of genocide, based on a highly selective and ideologically tainted understanding of the US military and the United States' historical relationship to genocide and other human rights abuses at home and around the world. ${ }^{10}$ Not a few genocide scholars seem to have accepted this, to the point where the discipline can appear at times hawkish. While it is unreasonable a priori to rule out military intervention, it is equally so to ignore many other avenues, particularly avenues of deep prevention. This is considered further at the end of this article. Suffice it here to state that every aspect of the relationship between the field of genocide studies and military institutions and every conceptual element of militarization must be subjected to ongoing critical analysis, and scholars must have the courage to point out the inappropriate militarization of the discipline despite the militarism prevailing in many countries globally, especially the United States. Scholars should be ever mindful of the fact that the tighter the discipline's connections to military interests, the less of a brake on military abuses of human rights the discipline will be. Even in cases of international peacekeeping forces, abuses are well-known. ${ }^{11}$ The militarization of genocide studies is functioning to pull a potential oppositional nexus against militarization and a broader abuse of human rights into the system that abuses human rights, so that it loses its critical edge and ability to position itself as a resistant force to the root causes of genocide, however much it might reject or lament the effects of genocide. 
Responsible scholars must continually evaluate the uses and abuses of scholarly research and teaching as well as the powers and interests at play in university and NGO settings in order to clarify continually the ideological dimensions of all scholarship in their chosen field. This is not to say that there is such a thing as "pure scholarship" that can be opposed to the various agendas and interests that, in two ways, have intruded into academia and/or appropriated its activities. First, regardless of a scholar's intentions, his or her work is always placed within and influenced by a social and political context. At the very least, every discussion of any aspect of genocide has potential political implications, as it can be used to justify a range of actions or inaction. Second, that a scholar is ethically or politically disinterested raises a question about why he or she is conducting research in this field. Those most committed to the notion of "disinterested" scholarship are too often those most interested in their own status within their fields. They do have an agenda, but not a broad political agenda in the service of others; they serve their own career interests in the sense of trying to raise their prominence in relation to other scholars and in the broader community. There is nothing inherently wrong with this and it might spur great scholarly achievements with important social utility, but it is false to claim that such scholars are "disinterested." What is more, too often in academia the personal agenda undercuts the potential social utility of the scholar's activities by focusing them exclusively on self-aggrandizement and self-benefit. This calls into question the objectivity of such scholars, who come to prize "original" ideas without regard to their correctness. Academia becomes an industrial engine devoted to generating "new" ideas, the main evaluation of which depends not on the lives they might save but on the extent to which they represent differences from received ideas. Scholars critique other scholars not out of genuine intellectual and social commitment but in order to demonstrate their own superiority-that is, in order to offer ideas that are superior to those critiqued in virtue of the fact that they come later. While new ideas are of course the lifeblood of scholarly research, this is so because they produce new and better understandings. Novelty and criticism for their own sake or as the demonstration of power are only valuable coincidentally, if they are valuable at all.

In the end, it is not a question of whether or not this or that scholar has an agenda-every scholar always already does—but of what that agenda is. ${ }^{12}$ In this light, the anti-activism bent is actually based on the principle that individual self-interest is more worthy than other-focused interests. Clearly, "other-focused" interests can include the worst of motivations, such as in Nazism, with an individual serving the promotion of the "Aryan master race," but just as clearly they can motivate efforts to overcome the oppression of others. There is no choosing a priori between "disinterested" scholarship (read: self-interested) or "interested" scholarship: responsible scholars must decide regarding each work of scholarship whether the agenda behind it undercuts its value for scholarly inquiry aimed at a better understanding of an issue-and, perhaps, addressing it, which is not precluded.

Just as some scholars are criticized for "activist" stances, in recent years selfadvocacy by former victim groups has drawn as much disapproval. The positive side is the frank discussion of certain forces within a victim community exploiting actual genocide histories and the suffering of victims. But too often scholars claiming objective indifference extend this criticism carelessly to all political agency by post-genocide victim groups, labeling their approach to genocide with the pejorative term "memory politics." The typical claim is that victim groups' political agency that challenges the 
post-genocide status quo and points out continuing harms by the perpetrator group, and perhaps advocates repair by the perpetrator group-which asserts basic categories of "perpetrator" and "victim," in fact-is based on misrepresentations or at least selective narratives of the genocide history toward some current political end. Again, this can be the case in some instances, but that abstract possibility is all too often unjustifiably assumed to be actual in all concrete cases.

Regarding this tendency, we might notice a number of things. As has been commented on before in reference to genocide and other kinds of oppression, only weak, dependent, deferential victims are considered true victims. When victims demonstrate their independent wills, especially in ways that conflict with the agendas or desires of the scholars or governmental or non-governmental individuals helping them, that agency is disparaged..$^{13}$ But this is a function of power. Victims in an objective sense have little power, precisely because of the degrading of their political, economic, cultural, social, familial, and other structures and strengths through genocide. While the most obvious way in which this plays out is the ability of the perpetrator group and successive generations not only to deny that genocide occurred but to continue to enjoy and extend the benefits accruing to them from it (in the form of land occupation, wealth expropriation, political power and legitimacy, identity superiority, etc.), it also structures the relationship between helpers and victims, which is just as much a power relationship. While some "helpers" are cognizant of this and consciously or naturally operate in ways that do not exploit and even mitigate the power differential, too many are not and do not. It has been argued, in fact, that precisely this kind of power is characteristic of, for instance, non-governmental international development work. What is more, a cursory examination of the relationships of third-party actors to perpetrator and to victim groups reveals a tendency to be much more deferential to the former than to the latter. As a function of power, victim groups' actions and attitudes are subjected to intense scrutiny, while even perpetrator denials are largely tolerated as expected behaviors, "free speech," and so forth.

This is evident in recent attention to the claimed tendency of victim groups to become subsequent perpetrators in what has been labeled "cycles of violence." ${ }^{14}$ There is no doubt that some victim groups become perpetrators. But this does not mean that victim groups in general have this tendency. The question to ask is not whether some victim groups become perpetrator groups, but whether the incidence of this among victim groups is higher than it is among non-victim groups. I am aware of no study of this particular issue, one researched for instance for individual crime, ${ }^{15}$ but an informal tally of cases of genocide in recent centuries would seem to indicate no special differential one way or another. The reality is that some victim groups commit genocide because some groups commit genocide. It seems a perverse extension of the dominational logic of genocide for victim groups to be subjected to disproportionate scrutiny and pre-emptive disapprobation because they are subjected to genocide. In this way, they seem to have to be punished for the transgressions of the actual perpetrators. It is quite interesting that the most prevalent link between past and future genocide is left under-discussed: the tendency to commit genocide again of past perpetrator groups whose genocidal acts are functions of embedded political, cultural, institutional, military, and other such forces, attitudes, and structures or whose genocidal acts have embedded in their societies militarist, political, and other attitudes and structures influenced by or reflecting genocide, when those groups are not challenged or rehabilitated to expunge the embedded elements. The United States, and the way in which genocide of Native Americans was a 
deeply embedded feature of the military, culture, and politics of the nineteenth century is a case in point: there is little mystery as to why the same military committed atrocities in Vietnam (against another indigenous group) or had intentional roles in the genocides in Guatemala, Indonesia, and East Timor. "Serial" genocide perpetrators slip under the radar as much now as genocide did relative to individual murder prior to Lemkin.

The memory politics tendency is to relegate victim group narratives, even when these deserve some criticism for simplifying group identities and genocidal dynamics, to an equivalence with perpetrator group narratives in being inherently flawed and reductive. Of course, no "narrative" of a genocide is free from some kind of reductionand this is true especially for accounts that emphasize the complex, multifaceted nature of a set of events considered a genocide to emphasize that no "grand narrative" fits them, as such accounts lose sight of any unifying factors and focus exclusively on the fragmentary character of the data-and even the best of yesterday's scholarship is subject to revision today. But even more important is understanding the context of the production of "narratives" of genocide. When victim group members understand their relationship with the perpetrator group as a tension between two discrete, defined groups, they could well be expressing a kind of reactive prejudice that excludes complicated members of their own group and progressive members of the perpetrator group. But they are more likely-or at least also-capturing the concrete material reality of the relationship, beyond rhetorical complexifications and effectively negligible countercurrents. For the result of genocide is an extreme domination relation between the perpetrator group and the victim group, both in terms of a maximized territorial, financial, political, and military disparity and of identity security, psychological and medical wellbeing, familial structures, cultural vibrancy or even survival, and so on. These are central to the lives of people in both groups even generations after a genocide. What is more, extensive progressive rhetoric among members of the perpetrator group has no effect against-indeed, can even buttress - the persisting devastating material and psychosocial impacts of a genocide, which not only render the typical victim group politically, economically, militarily, culturally, and socially marginal in the very long term but often worsen over time as the necessary social structures and institutions to support even group maintenance have been either devastatingly degraded or eliminated altogether through genocide and its aftermath. In the absence of substantial sacrifices on the part of the perpetrator group to mitigate these impacts to at least the extent necessary to stop further erosion and support the long-term viability of the victim group, reductive narratives of this relationship and history capture its actual reality in terms of the concrete effects of destruction. The complexities of both groups and countercurrents in each (for instance, prejudicial attitudes against the perpetrator group by victim group members) have negligible effects relative to the overall process of group destruction. While it might be true that what is labeled a cohesive "genocide" can be seen as a temporally and spatially extended multiplicity of acts that might or might not have been organized around intent from the early stages and whose agents might or might not have shared the same goals, intent is usually clear in the acts and even statements of key participants, and the complexities do not prevent the multiplicity of acts from having a relatively uniform and linear effect on the victim group.

A common mathematical notion might help to illustrate this point. A complex of forces might include very many individual forces pushing in all different directions with different magnitudes, but if the multitude of vectors resolve into a vector sum-that is, 
a single vector-of sufficient magnitude and pushing in the direction against victim group survival, then it is legitimate to write of a single genocidal process unified in its effects. The vector sum analogy is reductive in that it assumes that there is a clear set of individual vectors with single directions and magnitudes that are quantifiable, while in the case of a genocide component individual agents, acts, and statements are often complex in their motives and implications, so that it would be more accurate to refer to vector sums of vector sums, with perhaps even these components being complex and so forth. But the general model is sufficient to convey that claims that unified narratives of particular genocides are inherently inaccurate apply only to a simplified "straw man" narrative such that a relatively consistent effect is produced by data that tend all in the same direction - that is, a perpetrator group whose identical words and acts flow in exactly the same direction, uniformly against victims, without any countercurrents or complexity.

The shift toward the complex in genocide studies reflects perhaps a postmodern turn, away from Ockham's razor. Once one dispenses with the correspondence theory of truth - that there are simple facts in the world and, when one has contending accounts of some aspect of the world, which is true can be determined by determining which of the accounts corresponds accurately to the facts of the world-appeal is typically made to Ockham's razor, which is the view that among competing theories of the same data, all other things being equal, the simplest explanation is the best, that is, "true." We now seem to be in an era in which it is assumed that a simple explanation is inherently wrong and the truth is always complex, so a more complex explanation is always better than a simple one, even if it is not perfect. But there is nothing about complexity or simplicity that necessarily links either to truth; the truth can be complex or simple, and complex and simple theories can both be false. While this might seem to draw us back into a correspondence theory of truth, that is not the case: proponents of neither simplicity nor complexity can make a positive case for their view, regardless of the (independent) criterion of veracity used. The automatic valuing of "complexity" is perhaps more a reflection of the cultural domination of accumulative (typically capitalist) economics that more is better-in this case, more elements in an explanation-than it is the reflection of genuine epistemic inquiry.

It is also worth pointing out the resonances of the memory politics approach to post-genocide contexts with some of the more subtle and progressive denialist approaches to mass human rights violations including genocides. Consider Chizuko Ueno's rejection of Yoshiaki Yoshimi's documentary evidence of Japanese governmental organization of the "comfort women" system on the grounds that there is "no single, objective historical truth" 16 about a given matter and her view that former soldiers" misrepresentations of the treatment of comfort women are just as valid as any survivor's own testimony about what she actually experienced. This relativistic approach to competing narratives not only rejects obvious tools of critical analysis, such as the triangulation of multiple historical sources, but it also evidences a kind of vulgar postmodernism that contradicts the actual work of figures such as Derrida, who publically recognized the truth of the Armenian Genocide despite denialist narratives posing an alternative; Foucault, who recognized that brute facts of reality exist; and Lyotard, well-known for his engagement with Holocaust denial. While Ueno's work might be explained to result from simple naïveté and intellectual inadequacy, a more disturbing resonance is to the work of Norman Itzkowitz, who has consistently denied that the fate of Armenians ${ }^{17}$ under the Ottoman Empire was genocide. A decade ago I published a critique of 
Itzkowitz's historical method, ${ }^{18}$ which Itzkowitz had developed with Vamik Volkan. The method depended on the claim that all groups have "chosen traumas" that condition how they view their own histories and other groups around them. As long as groups focus on these past traumas, they cannot live in the present and rework their relations with other groups in a positive way. Thus, today both Armenians and Turks emphasize their historical traumas in narratives that portray members of the other group negatively as "others" 19 and fuel ethnocentric nationalisms. Both groups should give up attachment to their traumas. Of course, this approach equates denialist falsification, however sincerely believed, with a reasonably accurate historical account and asks the victim group to give up its accurate version of history while the perpetrator group is to give up its falsification, with the result that the falsification actually wins out because the accurate representation of history is set aside or suspended. The central concern in the article was that the framework adopted by Itzkowitz, which is clearly historically relativist in an untenable way, would have popular appeal because it appearsas so much in the repertoire of deniers-to instantiate tried and true methods of critical thinking, in this case suspicion of all historical narratives in light of contemporary politics. Were the model adopted broadly in academia, victim groups would have to accept victimization in terms of giving up pressure toward perpetrator responsibility and even giving up the ability to have the proper characterization of their experiences accepted and disseminated as the truth. To the extent that the current trend of memory politics discourse in genocide studies and elsewhere reflects this kind of methodology, the feared trend discussed in the article a decade ago has materialized.

Itzkowitz's work also anticipates another trend, the muddled use and overuse of the term "trauma." In genocide studies, conflict resolution and peace studies, and related disciplines, "trauma" has come to be used incessantly to mean any subjectively bad feeling with either a past or an external cause. But trauma has a precise clinical meaning. It is an extreme psychological state characterized by such things as fixation on past events, hypervigiliance, and many other symptoms induced by the experience of severe violence, related victimization (such as childhood sexual molestation), or loss. In this sense, "trauma" is not a feeling but the normal or expectable psychological register of extreme material harms. To say a genocide perpetrator group, such as "Turks," has a historical trauma deriving from the loss of empire is either nonsensical or changes the meaning of trauma to mean something like "any subjective bad feeling resulting from any historical change," in this case the change being a reduction in status from dramatic imperial domination of subject peoples to a more equal status. Yet, this kind of misapplication of the term is still afforded the psychological seriousness of genuine trauma. Thus, the faux trauma of the Turkish loss of empire (no one is entitled to an empire in the first place) is still seen to give contemporary Turks the status of victims who have been deeply harmed by history and whose psychological well-being is in danger and must be supported by care in reference to history, for instance, by not mentioning a genocide of Armenians. This article is not meant to be a sequence of prescriptions, but if there is one which it will make, it is that genocide scholars begin using "trauma" in a technically careful and precise manner, rather than loosely and vaguely. While not to my knowledge treated as the foundation of contemporary concepts of trauma, Bergson's detailed and precisely technical distinction between "memory image" and "pure memory" - the latter is a return through memory to the brain and physical states experienced at the moment when a memory was formed, while the former is merely a non-affective 
recall of the information contained in a given memory-could be very helpful in this regard. ${ }^{20}$ For Bergson, there are different forms of memory with very different kinds of functions, impacts, and epistemic statuses, a concept obscured in all too many discussions of "memory politics" and "trauma."

This criticism of the way "trauma" is often used might appear to be an attempt to regulate the discourse of genocide studies (and related areas). That is not the intent. On the contrary, a growing problem for genocide studies as a meaningful intellectual endeavor, and not a mere academic path, is its increasing institutionalization, that is, its organization into relatively settled, predictable academic methods and entities. Of course the growth in Holocaust, Holocaust and genocide, and genocide studies centers, courses, academic positions, and the like has benefits, not the least of which is to ensure wider and consistent attention to genocide driven by the dissemination of serious academic scholarship on it. But institutionalization also has its negative implications, as a once dynamic, cutting-edge challenge to received ideas and academic structures becomes staid and self-regulated. Academic institutionalization proceeds not simply by entrenching a discipline within university programs, permanent fixed funding, and so on, but also through a transformation of the positioning of the research, teaching, and service done and its originality. Even "original" work, which might be quite creative and occur in great volume, is captured within an institutionalized structure that organizes it in line with academic career trajectories much less than social and political change. Early scholars of genocide were in fact not scholars of genocide. They were legal scholars, philosophers, psychologists, historians, political scientists, anthropologists, sociologists, literary critics, art historians, economists, and others who took systematic mass violence as their object. Precisely because they had not cohered into a group with a defined identity through time, they made an effort at cross-fertilization that continually yielded fresh fruit. Typically as outliers in their home disciplines and without an academic identity group besides, they were positioned persistently to challenge disciplinary limitations through genuine attempts to develop theories and analyses of genocide and genocides. Each work of genocide scholarship required a positive effort to reassert the topic of study as legitimate.

After decades, we have passed through a balanced period of semi-outsider/semiinsider status-probably the 1990s and into the early 2000s-and now inhabit a space in which the discipline has a more and more defined identity (disputed to be sure) as well as clear associated academic positions, journals, conferences, and centers. New scholars of genocide do not create their own space but actually fit themselves into already established specializations and career tracks, graduate programs and professorial chairs, and scholarly schools or traditions. Scholarship becomes less a matter of generating new ideas and more a matter of taking sides along pre-given fault lines, in line with previously articulated positions, and mining research outside of genocide studies for useful ideas that can be applied to genocide. Funders, governments, and university administrators and faculty mold scholars through the manner in which they set up the various pathways for genocide scholars into and through academia, even as budding genocide scholars mold themselves (as they are trained to do in home disciplines). Even disciplinary boundaries and methods are imposed on and become generative of genocide studies (for instance, when a scholar decides to take a "public health" or a "philosophical" approach to genocide). ${ }^{21}$ While there is nothing wrong with using the tools available in a given discipline to understand genocide-on the contrary, genocide 
studies greatly benefits from the wide range of disciplines represented in it-when the disciplinal commitments become primary such that the discipline takes genocide as its object (because it is in vogue or for some other such consideration), the result is an articulation of the disciplinary bounds of an area of study and not insight into genocide. Genocide understood through such a framework becomes a construct. Only when scholarship is object-driven, such that all uses of disciplinary methods are checked against the demands of the object itself, is the object itself captured well through the methods. What is more, confrontation of an object that resists capture by existing disciplinal concepts and through existing methods is an important occasion that can spur advances in the discipline itself, but institutionalization tends to prevent this as comfortable traditions are merely extended and the object flattened into submission. Such a challenge that has yet to occur (but should) in my own field of philosophy, for instance, is a re-evaluation of classic critical thinking methods, evidentiary standards, and truth concepts as well as the development of new ones that can handle the deep epistemological crisis produced by prevalent genocide denial. This is particularly urgent because deniers typically warp the received methods-such as Descartes's method of critical doubting and Hume's critique of causal inference-to subvert truth rather than achieve it.

While the security that goes with institutionalization has benefits, in the end it threatens to obscure the point of genocide studies as the discipline becomes merely an academic specialization no different from the study of early modern Indian Ocean commerce, eighteenth-century German literature, or the mating habits of fruit flies. The disparagement of activist scholars (read: those doing scholarly research who do not fit into neat, traditional academic roles) shows just how far the institutionalization process has gone and just how little time might be left for meaningful contributions from the discipline. The pressure toward institutionalization and its eventual undercutting of a true intellectual movement as it becomes an academic discipline is perhaps inevitable, but it can be recognized, resisted, and slowed (a second prescription).

One sign of resilience of the genuine movement is that there are still frequent principled debates about core issues, such as freedom of speech and denial, that have much more than academic implications. But at the same time there appears to be more and more maneuvering within and among organizations, journals, and so forth focused on the development of power bases and the imposition of specific agendas and ideologies (and even some founding figures seem to participate in this). While the discipline is undoubtedly more vital than many others in academia, it increasingly resembles other disciplines as academic power dynamics under rhetorical cover play out as putative academic debates. Another sign of health is the work of figures such as Herb Hirsch and Alex Alvarez, who are questioning whether in the future we need to dramatically rethink our comfortable notions of how group destruction occurs, for instance, by recognizing the genocidal impact of climate change that could displace in importance earlier forms of genocide through military action. ${ }^{22}$

A similar trend, spear-headed by figures such as A. Dirk Moses, is to push the boundary of genocide into the traditional sphere of postcolonial theory, as discussed above. While denials of genocides of indigenous peoples in North and South America, Australia, and elsewhere are nothing new, the new application of post-colonial theory is important in responding to denial through structural analyses that identify features of colonialism and/or imperialism that tend toward genocide. This follows Ward 
Churchill's analysis of such factors as disease and starvation as apparently unintended consequences of contact between Europeans and indigenous Americans that lead to the dramatic demographic collapse of the latter. Churchill exposes the intent behind policies that, for instance, created conditions under which disease became rampant among indigenous populations. ${ }^{23}$ It is possible to extend Churchill's approach through an additional logical point that does not appear ever to be addressed by those who claim there was no genocide of indigenous Americans. Medieval and early modern European history is filled with disease epidemics with devastating demographic effects. If contact between Europeans and indigenous Americans had not been genocidal but the mere product of the passage of unfamiliar pathogens from one group to the other-without compounding, intended reductions of the resilience of one of the populations in question-then one would expect the pathways of pathogens to have run in both directions somewhat equally. But, where were the matching European epidemics, at least among settlers in the Americas? Why were these not transferred back to European populations through the return of voyagers? ${ }^{24}$ The obvious answer is that the trajectory of disease was not a function merely of the random exchange of pathogens, but occurred, as Churchill argues, in a context of direct biological warfare and/or the weakening of indigenous populations through other means, such as imposed starvation, food-source destruction, physical destruction, psychological trauma and family destruction, and so forth.

There have been other interesting recent developments around the issue of denial, for which genocide scholars deserve a significant amount of credit. One example is denial of the Armenian Genocide. ${ }^{25}$ Through their efforts as well as those of advocacy organizations, academic denial of the Armenian Genocide is less and less prevalent and tenable. Indeed, in recent years, those who claim that no Armenian Genocide occurred have moved more and more from academic debate to legal suits to gain legitimacy for their views. These include the lawsuit to force the inclusion of denialist sources on the recommended resource list for public school genocide education in Massachusetts and the suit against the University of Minnesota for its Holocaust and Genocide Studies Center identifying sources as "unreliable" that reject the veracity of the Armenian Genocide. ${ }^{26}$ This tactic is telling in two ways. First, it is evidence of just how marginal denial has become in academia. Second, it shows that those who claim that no Armenian Genocide occurred have taken the issue out of academia and placed it into the legal sphere. This is interesting in light of how often Armenian groups are criticized for "politicizing" the issue and not leaving history to historians. Of course, there is a specific danger here: the legalistic approach can function to intimidate into retreat those who would stand up against denial. Whether this intimidation succeeds in the long run or not will depend in part on the commitment of genocide scholars. The broader danger is that this tactic will be used again and again in the future against genocide scholars whose scholarship refutes denials of or establishes the truth of other genocides, such as the Nanjing Massacre, the Guatemala Genocide, and many others.

An apparent advance also occurred starting in the early 1990s through the intersection of feminist theory, particularly around violence against women, and genocide studies. Initial work such as Alexandra Stiglmayer's edited volume Mass Rape: The War against Women in Bosnia-Herzegovina ${ }^{27}$ was groundbreaking on a number of levels. Such work brought together the extensive literature on sexual assault and other violence against women, pornography, and related issues; the literature on militarization and violence against women; and nascent understandings of the roles of rape in genocide. 
The recognition that sexual violence against women and girls has been and remains rampant in military conflict as well as one-sided mass violence; that it has deep effects on the direct victims that undermine their ability to function in the future; that the effects on direct victims reverberate throughout their communities, for instance, by creating an impetus to leave the home territory with the result of dispersion and destruction of group identity which affects many more people in ways that the direct murder of a portion of the group probably could not; and so on was an important advance in the conceptualization of genocide and mass violence against women.

Other considerations can be added. First, sexism within victim communities that produces a problematic treatment of rape survivors or tension over rapes can contribute to group dissolution by means other than killing. Thus, because of a double layer of sexism, sexual assault becomes an effective alternative, especially because direct killing is much more likely to trigger outside condemnation and intervention while rape is so tolerated in the day-to-day existence of most societies that even mass rape evokes at best minor responses. ${ }^{28}$ Whereas murders become unifying rallying points for communities, condemned cohesively by members, rape often fragments a community along various lines. Second, rape can be inflicted on a victim again and again and again. It is deeply harmful physically and psychologically, but if the rapist(s) choose(s) it preserves the victim for further harm. Once a person is killed, short of corpse mutilation (often done in a sexualized manner), there is no further harm that can be inflicted. The excess of violence that is typical of genocide seems to call for more than direct killing alone can satisfy. This is, presumably, the reason gratuitous torture is so prevalent alongside rape.

By the 2000s, however, the connection between genocide and mass violence against women had been displaced by use of the term "gendercide," originally coined by Mary Anne Warren as a gender-neutral term denoting sex-selective extermination. ${ }^{29}$ Thus, gendercide refers to the Srebrenica massacre of thousands of Bosnian Muslim men and boys as much as it applies, for instance, to the rape of Tutsi women by HIV-infected perpetrators in the Rwanda Genocide. The gender neutrality of the term, as opposed to previous terms such as "femicide," is seen as important because male segments of populations are sometimes killed outright and in a short period and, in some cases, adult females appear to have survived at a higher rate than adult males from the victim group, ${ }^{30}$ which would suggest that in at least some genocides on average men have it somewhat worse than women.

Against the uniform approach typical of earlier scholarship on the Holocaust and, to an extent, other genocides, for scholarly understanding as well as prevention and postgenocide support, there is a value in recognizing that perpetrators often treat and use different methods for different segments of victim populations, and the latter often experience the genocidal process differently. The tool of gendercide allows a more nuanced, precise, and complex analysis of individual genocides and genocide generally. While the approach adds complexity in one dimension, however, it obscures other facts of genocide and is reductive in another. It approaches gender difference in a mechanistic and quantitative sense, focusing on the bare outcomes and not on the deep causal factors of contextual forces and structures. It is true that in some cases men are killed en masse and women more selectively, but that does not mean that the motivation for this is a desire to attack men simply because they are men. The hundreds of thousands of Armenian soldiers killed by the Young Turk regime at the beginning of the 
Armenian Genocide and the thousands of Bosnian Muslim men and boys killed at Srebrenica were not killed because the perpetrators acted out of prejudice against men. ${ }^{31}$ They were killed because they were Armenian or Bosnian Muslim men and their group in general was targeted. The gender differentiation was instrumental: in order to weaken the target group for fuller destruction or destructive dispersal, potential military resistance was eliminated. Indeed, these segments of the population were killed due to a sexist hierarchy of men over women, in which men, but not women, were considered inherently powerful and capable of military opposition, and socialized to be so. That in these instances sexism was detrimental to some men does not mean that it was not enacted by other, more powerful men-that is, the genocide perpetrators. The neutralist gendercide approach confuses correlations with gender-for instance, in a given case, men are disproportionately killed - with causation by gender-that these men are killed because the perpetrators want to kill men simply because of their maleness.

When women are raped (and often killed afterward), sexually enslaved, or subjected to other gender-specific violence in the context of genocide, it is true that the targeted women are targeted because of their ethnic, religious, national, racial, or some other group identity. It is also true that, for instance, in the former Yugoslavia Serbian forces used rape intentionally as a means to accomplish destruction of a targeted ethnoreligious group. But these factors do not exhaust the causal forces driving the use of rape. For instance, as Matthias Bjørnlund has argued, the massive sexual violence perpetrated against Armenian women and girls during deportations resulted from the removal of usual constraints on men's sexual aggression against women and girls and the effective creation of zones in which they had complete freedom to act on their misogynist attitudes and desires. ${ }^{32}$ It should go without saying that this does not mean that men have natural sexual energy that they need to discharge and will do so when given any opportunity or will do so through rape if other avenues for discharge are blocked. Such a naturalistic rationalization of rape and exoneration of men who practice it is not only insulting to men but deeply problematic in that it normalizes rape and shields it from moral evaluation. On the contrary, men rape in such contexts for a variety of reasons that are all socially derived, from the socially constructed view of women as inferior objects to peer pressure or military orders. Underlying all of these reasons is a fundamental but socially constructed hierarchy in which the domination of women is normalized and linked to pleasure. In other words, what produces rape is not the drive for sexual pleasure but rather the fact that violence has become sexual, that organic sexual pleasure for rapists has been replaced by "domination as pleasure," and that sexual gratification comes with domination rather than mutual sexual interaction. This explains why men who rape typically have ready access to sex by other means but choose to rape despite this. ${ }^{33}$

The upshot of this is that, to understand why women are treated as they are in genocide, one must include analysis of overarching or external systems of gender domination, which is a key aspect of the structural context in which genocide always takes place. Genocidal forms and activities are at least to an extent, and certainly in this dimension, culturally determined. Women and girls were raped because they were Chinese (Nanjing Massacre), Bengali (Bangladesh Genocide), and so forth, but also because they were female. Being female is a primary, not an instrumental or indirect, reason for violent treatment. In genocide, men are never victims as men but women are typically victims both as part of their identity groups and as women. In this regard, it is helpful 
to understand that, in a context of inequality, equal treatment of all people in a neutral manner regarding their differences actually reinforces or leaves in place the domination of one group by the other. Treating gender neutrally, that is, discounting the context of universal-if culturally variable in particulars - sexist hierarchy in which all acts of genocide occur, actually functions to obscure the real nature of the treatment of women and girls. While this is presumably not the intention of the advocates of the gendercide model, the approach resonates with the anti-feminist backlash movement that emerged in the 1980s and 1990s in the United States and its demand for equal attention to "men's victimization." 34

There is one important caveat to these critical points. As in the Holocaust, gay and bisexual men and transgendered individuals are frequent targets of deep oppression. Indeed, in the contemporary world, anti-gay/lesbian/bisexual/transgendered (GLBT) prejudice is expressed in a variety of forms, including formally discriminatory and even punitive laws that give official sanctions to the prejudices. This is largely tolerated despite the probability that if the same types of laws targeted people based on race, gender, or religion they would trigger massive global outcries. While anti-GLBT oppression and violence in the context of genocide or otherwise can be seen as oppression along sexuality lines, because of the deep intertwining of gender norms and sexuality ${ }^{35}$ when gay or bisexual men or transgendered individuals are targeted it should also be recognized as oppression of a segment of men based on exclusionary norms of gender identity, in the same way that the targeting of lesbian and bisexual women and transgendered individuals should be recognized in part as a function of sexism. Such men are targeted precisely because they violate the gender norms that are one of the foundations of the sexist hierarchy, and they are targeted primarily by men embracing that hierarchy.

The foregoing line of argument suggests an important insight into the relationship of genocide and violence against women. While the recognition of "rape as a tool of genocide" marks an important advance in the understanding of genocide and rape, this shift has not gone far enough. We must also recognize that genocide can be a tool of rape, at least for some perpetrators. It is not just that genocide frees (socially constructed) male sexual aggression or that it systematizes and organizes it instrumentally, but that male sexual aggression can motivate participation in and the destructiveness of genocide. It could even be a general motivating factor for genocide. Was rape central to Serbian aggression because the desire to rape was one of the constitutive causes of that aggression? In any event, it is clear that in case after case the opportunity to rape is a motivating factor for many participants. This is especially true when what could have been relatively restrained military deployments or conquests become hyperviolent destructions, as in Bangladesh. In such cases, the escalatory dynamic might have been driven in part by an increasing desire to rape on the ground and reflected in the attitudes of and condoned by those in power. At the very least, if some genocide perpetrators are motivated to participate by the possibility of raping, then in these contexts genocide is a tool of rape as much as rape is a tool of genocide. ${ }^{36}$ The complex ways in which masculinity is constructed through militarism and the high incidence of sexual violence within military violence confirm that young soldiers' sexualities are in part constructed along lines of "hypermasculinity" and sexist power over women, and the assertion of this masculinity becomes an end in itself. ${ }^{37}$

There is another side to this as well. Despite recent work on female participants in genocide, the vast majority of high-level perpetrators as well as ground-level killers, 
rapists, and so forth are male as propaganda and ruling myths are masculinist when gendered. This suggests that masculinity has a role in perpetration, which a neutralist approach to gender elides. When men are targeted as potential military threats, they are treated as male rivals in a dynamic of machismo aimed at establishing the supremacythat is, super-masculinity-of the dominant group. Even male rape can be seen as a function of patriarchal domination of women, confirming the above analysis. It is typically perpetrated by men and functions to "feminize" the victims, that is, to lower their status to that of women and girls. This is not to say that victim men choose to engage in or act as participants in this kind of macho contest; on the contrary, they often operate in ways that accept violence in the hope of sparing their families, which might be masculinist but at the same time is altruistic within the patriarchal framework typical of most societies historically and now. Within the typical gender hierarchy that exists in real terms in most if not all societies (both perpetrator and victim societies), prior to genocide the gender of women and girls already makes them fit targets of violence. Domestic violence has long been tolerated and encouraged in most societies and, despite apparent progress in "advanced" countries, it remains common to the point of prevalence in them as much as anywhere else. Rape is too often a rite of passage among various groups, from sports teams and fraternities to gangs and military units. When genocide begins, when the killers look for their targets, race or ethnicity is selected as the key criterion, but grafted onto it almost inevitably is the relish of making women and girls suffer through rape and other violence, enslavement, and more.

It is very important to stress that, even though the vast majority of perpetrators are men, the foregoing points of critique are not meant in any way to suggest that women suffer "more" than men in genocide-how could this be measured?-or to discount sexual violence against men, who need and deserve the same level of care, sympathy, and support as other victims of sexual violence. Rather, it is to point out that men's suffering in genocide is not a result of an anti-male agenda or prejudice, while women's suffering typically involves a layering of different causal forces that include male domination and misogyny. There is nothing in recognizing a truly existing gender hierarchy and its implications for genocide that requires or produces an inaccurate discounting of the actual suffering of men. To say that some part of women's suffering has a different genesis from that of men is not to say that male victims are not victims or suffer less horrifically in genocide. But it does say something about who perpetrators tend to be, why they perpetrate genocide, and why they do so in particular ways.

The recognition of the specific relationship between male domination and genocide is crucial for insight into the causes of the latter. If the analysis of that relationship in this article is correct, then pre-existing structures of gender hierarchy often contribute to the genocidal process. Indeed, rape, domestic violence, and other forms are preexisting vectors of violence that are widely and extensively tapped in the commission of genocide. This pre-existing vector of violence is a significant enabling factor of genocide. A challenge to the prevailing socialization of men and boys toward gender hierarchy, and more specific challenges to the role of violence against women in popular and pornographic culture, can help prevent genocides. ${ }^{38}$

A long-standing truism of genocide studies is that dehumanization is a necessary precursor. While dehumanization does occur in genocidal processes, the claim that it is an essential or typical causal factor is not necessarily true. Dehumanization is often the endpoint of the process, ${ }^{39}$ not its cause or the condition that allows it to occur. While 
space constraints preclude a consideration of detailed evidence, it is apparent that in many cases the genocidal process has depended on the recognition of the humanity of the victims. For instance, torture is more pleasurable for the perpetrator the more complex the mind of the victim - that is, the degree to which he or she can register multifaceted pain, dread repetition in the future, and so forth. The pain caused by raping individuals in front of their family members depends significantly on the complex human emotions experienced by the individual and the family. Similarly, forced choices about which child to save is an agony for human parents much more than for other animals. Thus, in many cases, perpetrators' calculations of pain infliction depend on the recognition of the human status of victims, in direct contradiction to dehumanization theory. In place of dehumanization, perpetrators assert their own exceptionality (sometimes superhumanity, as in the case of Nazi ideology), rendering themselves superior to victims in the same measure as dehumanization theory. ${ }^{40}$ The ethical dimension of that exceptionality is crucial: less than placing a certain group outside "the universe of obligation" as Helen Fein puts it, perpetrators grant themselves a virulent form of the ethical exceptionality identified by Kant in The Groundwork for the Metaphysics of Morals as an ethical trap, an exceptionality that gives them the right to do whatever they want to whomever they wish. ${ }^{41}$ This might help explain why genocide perpetrator groups tend to target multiple groups at once and/or over time, as in the case of the Nazis, the Young Turks, the Rwandan Interahamwe, the Khmer Rouge, the ultranationalist Serbs, Stalin's Soviet Union, the US, the UK, and so on. What is more, the dehumanization of victims might in part be a function of the inflated sense of superiority that perpetrators feel.

That is not to say that dehumanization theory is entirely wrong. Dehumanization can be an enabling factor for genocide. What is more, dehumanization theory captures a key element of genocide: the power or status differential between perpetrator and victim groups. The power differential is necessary to genocide, either as a beginning condition or sought outcome, but that differential might include any combination of victim and perpetrator group statuses so long as the perpetrators are dominant.

Many genocide scholars are so wedded to dehumanization theory, in my opinion, because of its ethical implications. Dehumanization theory explains genocide without attributing to perpetrators some primitive form of "evil," which is positive, but also without recognizing that human beings are perfectly capable, often for petty reasons, of wittingly and intentionally inflicting serious harm on other human beings, which is a problem. Rampant domestic violence globally shows just how much intentional violence against other human beings-intimate partners or children-is present in our day-to-day lives. It should be no surprise that these violent tendencies can be mobilized easily for other purposes as well. If so many can abuse their own family members, even to the extreme of sexual abuse or murder, how much easier is it to do violence to others, especially strangers? Dehumanization theory is actually a modern form of the Socratic/ Platonic view that wrong acts or harms are always done out of ignorance, never intentionally. That is, harm is a mistake, not an intended outcome. This old account of wrongdoing is comforting but naïve and not well-grounded. Indeed, it is advanced through some of Plato's weaker arguments, depending on equivocations, for instance, in the Meno. Over-reliance on dehumanization is an impediment to understanding why genocides occur and thus how to prevent them, in addition to allowing perpetrators, particularly mid- and lower-level ones, off the hook ethically to too great an extent. This is not to suggest that ignorance, manipulation, and so forth do not have roles 
especially for lower-level perpetrators, but that there is no simple either/or dichotomy regarding perpetrator responsibility for acts of genocide. Perpetrators must be evaluated on a continuum from full agency to coerced participation.

There are other totalizing tendencies among recent theories of genocide, including claims that all genocide is counterinsurgency ${ }^{42}$ and that (modern) genocide is a function of the nation-state system. ${ }^{43}$ While these and other similar theories are complex, nuanced, and tremendously fruitful as studies of genocide-in part because they bring into focus important elements of at least some genocides which are not always recognized or emphasized-any totalizing theory of genocide by its nature will require Ptolemaic stretches to cover a full range of cases. Genocides vary greatly in context, goals, causes, impacts, type of victim group, and other factors and simply cannot be reduced to a single explanation. For instance, the notion that genocide is colonialism is very important in drawing attention to the great extent of colonial genocide across the globe, especially over the past 520 years, and in highlighting features of genocides that are not typically understood through this framework. But the approach also constrains the analysis of cases that do not fit it perfectly. Colonialism is one kind of domination relation, but there are others and these can also be main or partial factors in genocide. A focus on power relations that could be colonialist, gendered, or national, among others, is the key to recognizing the various forms of genocide and the ways in which the phenomenon occurs in different contexts.

Totalizing theories also tend to reduce genocide to another, putatively more foundational, oppressive force, such as imperialism, capitalism, authoritarianism, nationalism, militarism, racism, or even mental illness. The question is, Why such a reduction? Given the prevalence of genocide across political and economic systems and throughout human history, in a manner similar to sexism, why should it not be seen as an elemental form of oppression? Why is the impetus to group destruction any less primary than the differential treatment of people based on religion or ethnicity? It is true that genocide might be committed as part of a broader process of colonization or slavery, but slavery, for instance, is also a typical element in genocide. Such forms of oppression all have explanatory value and in practice often overlap or interact. Rather than a reduction of some to others or one, it would appear more fruitful to examine the complex ways in which these forces intermingle in different instances of violence and oppression.

There is a danger in reducing genocide to other social forces or oppressions. We might come to believe that if we eliminate the other force or oppression, we will eliminate genocide. But genocide has persisted throughout dramatic historical changes; for instance, simply doing away with nation-states is unlikely to change that. We might see new forms of genocide appropriate to the features of a new historical era, but genocide will likely persist unless it is directly addressed. ${ }^{44}$

At the same time, genocide's intertwining with other forms of oppression and oppressive structures, including colonialism, imperialism, racism, chauvinist nationalism, sexism, slavery, apartheid, religious intolerance, anti-Semitism, and homophobia, has important implications for prevention. Much attention has been given to both intervention and early warning. The problem with intervention, especially military, is that it either comes too late to stop much of the impact or it introduces new power dynamics, oppressions, and human rights violations even as it puts an end to the old ones. Early warning is seen as an alternative, allowing steps way in advance of a potential genocide so that disruptive intervention is not necessary. ${ }^{45}$ But this focus on early warning is 
problematic in two ways. First, early warning is not particularly difficult to achieve, nor is its failure what has allowed genocide to occur in recent years. The "world community" had plenty of warning about the Rwandan Genocide, while it stood by for years as genocide unfolded in both Bosnia and Sudan. Of course, there are those who would dispute the characterization of both of these latter cases as genocide, but that is not the real reason that they were treated with indifference; even if they are taken as mass human rights violations, based on commonly accepted human rights principles, they clearly should have been stopped in a timely manner.

But these failures were not contingent absences of "political will," either, which brings us to the second problem. Genocide is not a surface phenomenon inconsonant with the broader social, political, economic, and cultural forces shaping our reality. It is, on the contrary, deeply embedded within them as a constitutive element. The world we inhabit has been shaped by genocide in conjunction with the other oppressive forces and structures listed above. Genocide has become normalized as a frequent violation of our stated standards of behavior that is tolerated if not condoned because it is part of the very historical development of our world. ${ }^{46}$ States such as the United States, Turkey, and Australia exist in their present form or at all through genocide. The problem of genocide is deep and foundational, and extirpating it requires a substantial reworking of our present reality. This is the fact that is avoided in discussions of early warning, intervention, and prevention.

Clearly there is resistance to recognizing the true challenge of the implication of so much of our world in the problem. Part of the resistance in genocide studies circles reflects a general wariness of revolutionary transformation. As Robert Melson especially has argued, ${ }^{47}$ some genocides have their origins in revolutionary movements. More generally, revolution is an extreme political activity, and the history of extreme political activity that is genocidal counsels that all extreme political activity be engaged in cautiously or avoided. But this fails to distinguish different kinds of radical political transformation and to register that, so long as genocide is part of the current sociopolitical order, centrist politics reinforce the normalization of genocide. Given the foundational centrality of genocide and other oppression to the world today, it would seem that only radical transformation can address the problem: great problems require substantial responses, and early warning systems and advocacy organizations fall well below the threshold.

One mechanism of transformation has already emerged. A decade ago, in most academic, popular, and political circles, the notion of reparation for genocide and other mass human rights violations was typically dismissed as fantastic and extreme. But, since then, a global reparations movement has emerged that connects a range of victim groups, including a number of genocide victim groups, seeking long-term justice. ${ }^{48}$ Reparation is often misunderstood as a backward-focused remedy that attempts to return victims to their pre-genocide state. This is of course impossible, and only a small part of the great material, social, and cultural harm done by genocide can ever be addressed after it has occurred, while the human harm is beyond repair. But the true function of group reparations is a reworking of current conditions to restore the viability of a victim group against the past genocidal assault. Accomplishing this requires a significant shift in resources and power, which can advance a broader transformation away from genocide. As the impacts of particular genocides are addressed, the world more broadly will become less a function of genocide and genocide will become less a part of that world. 
Space constraints prevent a full discussion of this line of analysis, but the field of genocide studies and its practitioners would seem to be at a crossroads. One path leads toward surface engagements with genocide for the foreseeable future, while the other offers opportunities to change the dynamics that produce genocide.

Henry Theriault is Professor in and Chair of the Worcester State University Philosophy Department. His research and teaching interests include long-term justice for genocide, perpetrator-victim relations, denial, and mass violence against women. He has published numerous articles, has lectured around the world, and chairs the Armenian Genocide Reparations Study Group.

\section{Notes}

1. This article is dedicated to the memory of my friend and mentor Robert John Ackermann, 1933-2011.

2. Criticized, for instance, in the literature on colonialism and genocide (such as by A. Dirk Moses) and in many presentations and discussions at the "Conflict, Memory, and Reconciliation: Bridging Past, Present, and Future" symposium held in Kigali, Rwanda, January 10 to 13 . The symposium was a program of the School for International Training (USA) in conjunction with the Rwandan National University Center for Conflict Management.

3. On the limitations of the notion of genocide as killing only, see Donna-Lee Frieze, "Cycles of Genocide, Stories of Denial: Atom Egoyan's Ararat," Genocide Studies and Prevention 3,2 (2008): 243-62, http:// dx.doi.org/10.3138/gsp.3.2.243.

4. See Henry Theriault, "Genocidal Mutation and the Challenge of Definition," Metaphilosophy 41,4 (2010): 481-525, 487-8.

5. Samantha Power, "A Problem from Hell": American and the Age of Genocide (New York: Basic Books, 2002), 17-78.

6. American Ambassador, Constantinople, to Secretary of State, Washington, Telegram 858, Jul 16, 1 pm, in United States Official Records on the Armenian Genocide, 1915-1917, compiled by Ara Sarafian (Princeton, NJ: Gomidas Institute, 2004), 55.

7. See, for instance, Henry Theriault, "Plato, Rousseau, and Western Philosophy's Anti-Genocidal Strain," in Metacide: In the Pursuit of Excellence (New York: Rodopi, 2010), 193-210.

8. See Henry Theriault, "The Albright-Cohen Report: From Realpolitik Fantasy to Realist Ethics," Genocide Studies and Prevention 4,2 (2009): 201-10, http://dx.doi.org/10.3138/gsp.4.2.201. For the full report, see Madeleine K. Albright and William S. Cohen, Preventing Genocide: A Blueprint for U.S. Policymakers (Washington, DC: Genocide Prevention Task Force, 2008).

9. Sarah Sewall, Dwight Raymond, and Sally Chin, MARO: Mass Atrocity Response Operations: A Military Planning Handbook (Cambridge, MA: Harvard University, 2010).

10. See Colin Tatz, "Genocide Studies: An Australian Perspective," Genocide Studies and Prevention 6,3 (2011): 232-45, http://dx.doi.org/10.3138/gsp.6.3.232, 236, and Henry C. Theriault, "The MARO Handbook: New Possibilities or the Same Old Militarism?," Genocide Studies and Prevention 6,1 (2011): 7-31, http://dx.doi.org/10.3138/gsp.6.1.7, 25-6.

11. See, for instance, Sarah Elizabeth Mendelson, Barracks and Brothels: Peacekeepers and Human Trafficking in the Balkans (Washington, DC: Center for Strategic and International Studies, 2005).

12. This position, though not directly from Stanley Fish, owes its general conceptual outlines to his treatment of institutional culture in “There's No Such Thing as Free Speech, and It's a Good Thing Too," in Ethical Theory and Social Issues: Historical Texts and Contemporary Readings, ed. David Theo Goldberg, 2nd ed. (Orlando: Harcourt Brace, 1995), 366-77.

13. This is often betrayed by disparaging remarks about "nationalist" members of victim groups and similar labeling.

14. This was a continuing motif across a number of papers, including some plenary sessions, at the Universitair Centrum Sint-Ignatius Antwerpen's international workshop, "Preventing Genocide: Root Causes and Coping Strategies" (University of Antwerp, 24-25 Nov 2011).

15. See Hugo Adam Bedau, "Capital Punishment," in Goldberg, Ethical Theory, 505-14, 506.

16. Suzanne O’Brien, “Translatoor's Introduction,” in Yoshiaki Yoshimi, Comfort Women: Sexual Slavery in the Japanese Military During World War II, trans. Suzanne O’Brien (New York: Columbia UP, 2000), $1-21,14$.

17. The present discussion reflects Itzkowitz's focus on Armenians. It should be kept in mind that Assyrians and Greeks were also subjected to genocide as part of the same overarching process in the Ottoman Empire. 
18. Hank $[s i c]$ Theriault, "Universal Social Theory and the Denial of Genocide: Norman Itzkowitz Revisited," Journal of Genocide Research 3,2 (Jun 2001): 241-56.

19. The imprecise overuse of this term from Simone de Beauvoir could be the subject of a full article in its own right. See de Beauvoir, The Second Sex, trans. H.M. Parshley (New York: Vintage, 1989).

20. Henri Bergson, Matter and Memory, trans. Nancy Margaret Paul and W. Scott Palmer (Mineola, NY: Dover, 2004).

21. A "philosophical approach," for instance, is likely to impose a notion of genocide derived from a limited concept of the person. It will probably assume an "atomic individual" view of the person, such that groups are only aggregates of individuals and matter only insofar as they yield identity benefits (a sense of belonging, a social context for personal development, etc.) to individuals. Group harms, such as genocides, are then understood to impose harms which are ultimately reducible to harms to individuals. See, for example, Stephen Winter, "On the Possibilities of Group Injury," in Genocide's Aftermath: Responsibility and Repair, ed. Claudia Card and Armen T. Marsoobian (Malden, MA: Blackwell, 2007), 111-31. Rather than trying to understand genocides on their own terms and building a theory of groups and individuals from genocide, this approach imposes a pre-existing belief on genocide and forces genocide as an object of study to conform to the terms of that belief. But those who study genocide almost invariably recognize it as more than a set of individual harms; otherwise, laws against individual murder and other violence would suffice against genocide. Ultimately, the atomic individualist approach conflates the fact that individual consciousness is where group harm is registered and recorded (psychologically) with the actual nature of the harm, which destroys group structures. That harms are only registered consciously in individual beings does not mean that the reality of the harm only affects individuals as individuals and that the group cannot be harmed as a group.

22. Herb Hirsch, "The Genocide Prevention Task Force: Recycling People and Policy," Genocide Studies and Prevention 4,2 (2009): 153-4, http://dx.doi.org/10.3138/gsp.4.2.153, 154, and Alex Alvarez, "New Perspectives on What Causes Genocide" (paper presented at the International Association of Genocide Scholars, International Institute for Genocide and Human Rights Studies, and Editors of Genocide Studies and Prevention jointly organized "Symposium on the Genocide Prevention Task Force Report," Woodrow Wilson International Center for Scholars, Washington, DC, 13 Mar 2009).

23. Ward Churchill, A Little Matter of Genocide: Holocaust and Denial in the Americas 1492 to the Present (San Francisco: City Lights, 1997), especially 137-46.

24. Theriault, "Genocidal Mutation," 505.

25. Again, the focus of denial efforts is on the Armenian case, though this indicates just how successful the omission of the Assyrian and Greek cases has been.

26. See "U.S. Supreme Court Rejects Massachusetts Genocide Denial Lawsuit," The Armenian Weekly, 19 Jan 2011, http://www.armenianweekly.com/2011/01/19/u-s-supreme-court-rejects-massachusettsgenocide-denial-lawsuit/ (accessed 10 Feb 2012), and Scott Jaschik, "Suit Over 'Unreliable' Websites," Inside Higher Ed, 1 Dec 2010, http://www.insidehighered.com/news/2010/12/01/minnesota\#Comments (accessed $10 \mathrm{Feb} 2012$ ).

27. Alexandra Stiglmayer, ed., Mass Rape: The War against Women in Bosnia-Herzegovina (Lincoln, NE: U of Nebraska P, 1994).

28. See the point above about intervention against Bosnian Serb aggression only after the Srebrenica massacre, despite years of mass rape.

29. See Adam Jones, "Gendercide and Genocide," Journal of Genocide Research 2,2 (2000): 185-211.

30. Ibid. The general line of argument of the following critique and certain key features are sketched by Warren herself in response to the anticipated misuse of the concept of "gendercide" to obscure rather than elucidate men's mass violence against women and girls, as presented here. See Mary Anne Warren, Gendercide: The Implications of Sex Selection (Totowa, NJ: Rowman \& Allanheld, 1985), 1-2.

31. This follows Marilyn Frye's analysis of "oppression," in The Politics of Reality: Essays in Feminist Theory (Freedom, CA: Crossing Press, 1983), 1-16.

32. Matthias Bjørnlund, "'A Fate Worse than Dying': Sexual Violence during the Armenian Genocide," in Brutality and Desire: War and Sexuality in Europe's Twentieth Century, ed. Dagmar Herzog (Basingstoke, UK: Palgrave Macmillan, 2009), 16-58, 24-5.

33. See, for example, Yoshimi, Comfort Women, 66-8.

34. An example of this occurred at the 2009 IAGS 8th Biennial Conference, when in a session on violence against women in genocide, audience member Geoff Hill emphasized the importance of male rape and suggested that it is an especially pressing problem because it is so marginal in discussions of sexual violence. This ignored the rates of committal (statistics do matter, as in the case of witch hunting, which did target men too but in smaller percentages, or anorexia-nervosa, which does afflict men as well but in much smaller percentages) and the crucial structural dimension discussed in this article. As Catherine 
A. MacKinnon has written, one of the ways in which the fundamental global problem of sexual assault against women and girls is downplayed and work against it is undermined, which supports the continuation of this violence, is criticism of activists and scholars for their "lack of neutrality in not considering rapes of men to be a comparable emergency" (MacKinnon, "Rape, Genocide, and Women's Human Rights," in Mass Rape, 183-96, 186). To understand the scale of rape of women and girls, looking at just the perhaps 200,000 comfort women between 1931 and 1945, one can estimate that on the order of 200,000,000 acts of rape were perpetrated against them. This is a staggering number and suggests billions of acts of rape overall during World War II violence. This points to a related issue: each act of rape-and gang rapes include multiple acts-should be recognized fully so that we no longer write of "raped women" (a problematic term for other reasons as well) but of specific acts of rape. A mere count of the number of distinct women who are raped can obscure the true extent of the violence.

35. See Robert John Ackermann, Heterogeneities: Race, Gender, Class, Nation, and State (Amherst, MA: U of Massachusetts P, 1995), 53-78.

36. Henry Theriault, "Rape as a Tool of Genocide or Genocide as a Tool of Rape?" (paper presented at the 8th Biennial Conference of the International Association of Genocide Scholars, George Mason University, Arlington, 8 Jun 2009).

37. See Ruth Seifert, "Rape: A Preliminary Analysis," in Stiglmayer, Mass Rape, 54-72, 59-62.

38. This point is at the intersection of Elisa von Joeden-Forgey, "The Missing Link: Gender and an Early Warning System" (paper presented at the 8th Biennial Conference of the International Association of Genocide Scholars, George Mason University, Arlington, 8 Jun 2009) and two articles by MacKinnon: Catherine A. MacKinnon, "Turning Rape into Pornography: Postmodern Genocide," in Stiglemayer, 73-81; and MacKinnon, "Rape, Genocide, and Women's Human Rights.”

39. Morgan Blum, "Dehumanization as a Process of Genocide" (undergraduate honors thesis, Clark University, 2002).

40. Henry Theriault, "Rethinking Dehumanization in Genocide," in The Armenian Genocide: Cultural and Ethical Legacies, ed. Richard G. Hovannisian (New Brunswick, NJ: Transaction, 2007), 27-40.

41. Helen Fein, Accounting for Genocide: National Responses and Jewish Victimization during the Holocaust (New York: Free Press, 1979), 9; Immanuel Kant, The Groundwork for the Metaphysics of Morals, trans. H.J. Paton (London: Hutchinson, 1948).

42. A. Dirk Moses, "Moving the Genocide Debate Beyond the History Wars," Australian Journal of Politics and History 54,2 (2008): 248-70.

43. Mark Levene, Genocide in the Age of the Nation State, vol. 1, The Meaning of Genocide (London: I.B. Taurus, 2005).

44. This follows Etienne Balibar's analysis of “neo-racism” in "Is There a 'Neo-Racism'?, in Race, Nation, Class: Ambiguous Identities, trans. Chris Turner (London: Verso, 1991), 17-28.

45. See, for instance, Albright and Cohen, Preventing Genocide, 17-53.

46. This is true despite the case of East Timor, which is one of the few instances of genocide in which at least partial prevention can be claimed. Intervention came in the form of the withdrawal of support for the Suharto regime that had renewed its genocidal assault on East Timor in 1999, an assault originally begun in 1975. This withdrawal did prevent an escalation of violence after a few thousand were killed. At the same time, the shift in US, British, and Australian policies derived from changes in the geopolitical situation and in particular the viability of Suharto as a pro-US, pro-British, and pro-Australian leader. Different from 1975, in 1999 genocide was no longer geopolitically sanctioned. Had it been, it would have been allowed to occur.

47. Robert Melson, Revolution and Genocide: On the Origins of the Armenian Genocide and the Holocaust (Chicago: U of Chicago P, 1992).

48. A meaningful step in and reflection on this process was Whose Debt? Whose Responsibility?, an international symposium on reparations held at Worcester State University on 10 Dec 2005, featuring papers on South African, African American, Native American, "comfort women," Armenian, and a number of other reparations issues and co-organized by world-renowned human rights activist Dennis Brutus and me. 